\title{
Kristendommen og religionerne ${ }^{1}$
}

\author{
Professor Dr. Robert W. Jenson
}

Abstract: In the present article, Robert W. Jenson argues against the commonly used simile that all religions are only different paths leading to the top of the same mountain. Instead, it is suggested that religions should be seen as different mountains with many similar paths. From this simile, and from the Church's founding message, it follows that the conversation between the church and the religions must be one of mission. In the course of the article Jenson discusses the relationship between reason and revelation, explains the relevance of the incarnation, and reflects upon the prospects and difficulties of Christian conversation with Islam.

Key words: Faith - inter-religious conversation - Islam - mission - reason and revelation - theology of religions

\section{I}

Der er et billede, der ofte anvendes for at illustrere sammenhængen mellem "religionerne": religion er som et bjerg med forskellige veje, der alle fører opad. Men selvom vejene så sandelig er mangfoldige, må de alle nødvendigvis nå den samme bjergtop.

Dette billede forekommer mig simpelthen at være fuldstændig forkert. Først og fremmest er religion ikke en entitet, som et bjerg kan være et billede på. "Religion" er en betegnelse for en klasse, som moderniteten har skabt for alle mulige forskellige fænomener, som den fandt det bekvemt at slå sammen i én gruppe. Denne fremgangsmåde er i sig selv problematisk. Og uanset om en sådan klassifikation er rimelig eller ej, så er det, der får os til at opfinde denne klasse, så afgjort ikke, at alle vejene har det samme endemål, hvad der, så vidt vi ved, ikke er tilfældet. Det er snarere vejenes sammenlignelighed, der ligger til grund for denne klassifikation.

Derfor ville et mere rammende billede være noget i denne retning: der er mange forskellige bjerge, som mennesket kan bestige, hvert

1. Oprindeligt holdt som foredrag torsdag den 24. september 2009 i Kældercafeen, Det Teologiske Fakultet, Københavns Universitet. 
med sin unikke top. Men de aktiviteter, der konstituerer vejene op ad nogle af disse bjerge - bøn, meditation, ofringer, sakramentale handlinger, tekstlæsning osv. - er ofte temmelig lig hinanden. Det betyder imidlertid ikke, at hver enkelt såkaldt "religion" ikke har sine egne unikke praksisser; men overlappene mellem disse praksisser er måske lige netop tilstrækkelige til at retfærdiggøre vores konstruktion af klassifikationen - lidt ligesom Wittgensteins billede af et stykke reb, hvis enkelte delstykker ikke i sig selv når fra den ene ende til den anden, men som alligevel udgør ét helt reb.

Således opfatter for eksempel buddhismen toppen af sit bjerg som den totale udslettelse af al personlighed, mens kristendommen opfatter toppen af sit bjerg som personlighedens evige virkeliggørelse i en tre-personal Gud. Taget for pålydende er disse uden tvivl forskellige bjergtoppe. Hvis nogle teoretikere ikke desto mindre stadig vil fastholde, at buddhismen og kristendommen må nå til en eller anden - i så fald komplet ubeskrivelig - fælles bjergtop, et endemål, som ingen af de mennesker, der faktisk bestiger bjergene, har for øje, er det ikke udtryk for andet end ren og skær ideologi, dvs. en påstand, som alene understøttes af en forudgående insisteren på, at sådan må og skal det være.

I realiteten er der mange bjerge. Disse bjerge, i det mindste nogle af dem, er endda udstyret med talrige veje; i en kristen jargon kunne vi kalde dem "spiritualiteter", ifølge buddhistisk terminologi hedder de "fartøjer", osv. Men der findes ikke et enkelt bjerg, som alle veje fører opad.

I forhold til nærværende emne er den umiddelbare konsekvens af ovenstående analyse følgende: enhver religions forhold til de øvrige religioner må være unik for den pågældende religion. Hvis vi presser vores billede endnu en gang og forestiller os et kort med prikker, der hver markerer et bjerg - som vi så vælger at kalde "religioner" - så vil relationen mellem hvert bjerg og de øvrige af geometrisk nødvendighed være unik; og at bevæge sig fra vejen op af ét af bjergene til vejen op af et andet vil indebære en flyvetur, der er forskellig i forhold til turen fra hvert af de øvrige bjerge. Og med det, tror jeg, at vi skal lade billedet ligge i denne omgang.

Men hvad er så kristendommens særegne relation til andre religioner? Jeg vil forslå følgende: den er bestemt af to specifikke væsenstræk ved troen. Det ene: kristendommen er en missionerende religion, ja, dens bestandighed er identisk med selve missionen. Netop her svigter bjergbilledet os, i begge dets versioner. Det andet: kristendommen kan ikke antage, at dens Herre har ladet visse af sine skabninger være uden nogen form for vidnesbyrd om hans herlighed. Jeg vil se nærmere på disse to bestemmelser og i nævnte rækkefølge. 
Det der gør en kristen til kristen, er ikke - $\mathrm{i}$ hvert fald hvis vi konsulterer Det Nye Testamente - en bestemt religiøs oplevelse eller en moralsk grundindstilling eller en verdensanskuelse - selvom alt dette med tiden vil gøre sig gældende. Hvad der gør en kristen til kristen, er at have mødt en eller anden, der forkynder et budskab - nemlig at Israels Gud har oprejst sin tjener Jesus fra de døde - og derpå at handle ud fra en overbevisning om, at dette er sandt.

Hvis Israels Gud virkelig har oprejst Jesus, hvis den opstandelse, som Israels sidste profeter forkyndte, er begyndt, så er dette en afgørende og vidunderlig sandhed om den virkelighed, alle personer lever i. Hvis vi kender denne sandhed og alligevel vælger at holde den for os selv, er vi ganske enkelt frygteligt selviske personer. Den kristne mission behøver ingen videre årsag eller begrundelse. Peter er nødt til at fortælle Portia om Jesus og hans opstandelse, og hvis Portia tror det, er hun nødt til af fortælle det til Hussein og så videre. Og således opstår det fællesskab bestående af Peter og Portia og Hussein og så videre, som vi kalder kirken. Med jævne mellemrum støder man på aktivister, der hævder, at kirken simpelthen er en mission. På grund af deres sædvanlige fremtoning og de følelsesmæssige hæmninger, der skyldes mine norske aner, så gør den slags mennesker mig som regel utilpas, men de har ret.

Siden dens begyndelse har kirken overvundet enhver kulturel og historisk forhindring, den er stødt på. Og det har den gjort, fordi den var nødt til det, slet og ret for at være sig selv. For kirken er græsset for at bruge en almindelig talemåde - altid grønnere på den anden side af en eller anden kulturel eller tidslig hæk. Eller måske rettere, høsten er altid bedre. Derfor invaderede de troende straks, i den ene retning, den almindelige senantikke middelhavskultur og spredte sig med ufattelig hastighed, i den anden retning, ud over Mesopotamien og Persien. Og da den senantikke middelhavskultur kollapsede rundt om kirken, og dermed stillede den overfor en historisk snarere end en kulturel hæk, så sprang den også over denne forhindring og skabte en ny kultur oven på ruinerne af den gamle.

Når nu missionen trænger ind $i$ en eller anden ny kultur eller ind $i$ en ny epoke i en indtil da velkonsolideret kultur, finder den aldrig denne nye arena religiøst, moralsk eller metafysisk ubeboet. Den vil allerede være optaget af nogle guder og af nogle dermed overensstemmende moralkodekser og metafysiske forudsætninger. Og de, der tilbeder disse guder og følger den pågældende moral, vil i de kristnes påstande om Kristus finde meget, der vil slå dem med forundring, og endda meget, der vil forarge dem. Da missionen langt om længe nåe- 
de vores nordlige egne, var vores forfædre ikke synderlig ivrige efter at overtage den nye tro - ja, det er endda blevet antydet, at de aldrig gjorde det!

Således kunne Athens elite godt forbinde myterne om guder, der døde og blev genfødt i en evig cyklus, med noget meningsfuldt, fordi de kunne ses som repræsentanter for virkelighedens tidløse dyb. Men hvad var nu det med en opstandelse, der én gang for alle gør en ende på døden? Hvad i alverden kunne der ske derefter? Eller samme situation, set fra den folkelige teologiske kultur i senantikken i middelhavsområdet: I hævder, at denne Kristus er en slags anden identitet i Gud? Og alligevel hævder I at tilbede én Gud? Hvad i alverden kan dette "er" så betyde? Eller nok engang den samme situation, nu bare set fra den vestlige Oplysning: Det er naturligvis kun det metafysiske og aldrig det historiske, der gør os salige. Hvilken mulig universel forskel, spurgte det 18. århundredes eliter, skulle en tilfældig, fortidig jødes opstandelse kunne bevirke i mit liv som europæisk kosmopolit? Med mindre han eventuelt havde en universel lære?

Der er ingen vej udenom: missionen må konfrontere de spørgsmål, mulige tilnærmelser og modstande, der udgår fra det senantikke middelhavsområdes forudeksisterende religion og moral eller fra Persien eller fra Skandinavien eller fra det postkommunistiske Kina eller.... Missionen har uden undtagelser fundet dette muligt! Og det er det forunderlige!

Missionen opfatter aldrig de spørgsmål, der opstår i de kulturer, den henvender sig til, som fuldkommen meningsløse. Heller ikke engang de modargumenter, den bombarderes med, kan den se udelukkende som en samling vildfarelser. I menneskehedens teologi og moral må vi altid regne med en blanding, ja med en samtidig tilstedeværelse af sandhed og løgn, af nonsens og dyb indsigt.

Kirkefædrene havde som regel øje for denne pointe. Af alle disse holder jeg mest af Klemens af Alexandria. Han bruger det meste af sin bog om de hedenske grækeres religion på at bebrejde dem, at de tilbeder skabninger i stedet for Skaberen. Men så standser han pludselig op og siger: "Men vi fortvivler ikke aldeles over jer. Der er nogle, med hvem vi kan føre en nyttig samtale", citerer derpå en passage fra Platon om erkendelse af det guddommelige, og bruger så resten af bogens sider på en fredsommelig diskussion af dette spørgsmål.

\section{III}

Hvordan skal vi forklare dette fænomen? Hvis vi bliver indenfor vores egen tradition, så har den historisk set dominerende forklaring 
været begrebsliggjort, med forskellig vægtning, som "fornuft og åbenbaring" eller "natur og overnatur". Den underliggende forestilling er baseret på tanken om et overlap: der er faktisk nogle ting, som Platon eller Aristoteles på den ene side og den kristne lære på den anden har tilfælles, og der er nogle ting, som Platon og Aristoteles ikke kunne vide noget om, men som de kristne ved. Hvis vi tænker i "fornuft og åbenbaring", så er der sandheder om Gud og menneskelivet, som kan erkendes med den fornuft, der hører til Guds menneskeskabning som sådan, og andre sandheder, der kræver, at Gud føjer noget til. Hvis vi tænker i "naturlig og overnaturlig", så er det naturligt for os at være knyttede til Gud og derfor, inden for denne relation, at have en virkelig erkendelse af ham, men den gave, som den frelsende relation til Gud er, og den erkendelse, der er indbygget heri, er en gave udover dem, der er givet med vores natur.

Hele denne konstruktion forekommer mig, hvor bekvem den end er i visse sammenhænge, at hvile på en i sidste ende katastrofal fejltagelse: at Platons eller Aristoteles' teologi ikke var afledt af nogen form for åbenbaring, at den ganske enkelt var "naturlig" for dem, at de kom frem til den gennem ren "fornuftserkendelse".

Hvis vi skal tage de græske teologer på ordet, får vi et ganske andet billede. Således fortæller den store og epokegørende Parmenides, at han på Elias-manér på hesteryg blev revet op til himlens porte, hvor gudinden åbenbarede et evangelium for ham, nemlig at Fader Tid ikke sluger sine børn, eftersom han, idet væren er tidsløs, slet ikke eksisterer. Hele beretningen minder på mange måder om stilen i de jødisk-kristne apokalyptiske profetier. Eller tag Homer. De guder, han som bekendt "gav til Hellas", er guder af en meget specifik type, veltilpassede til Parmenides' syn; for deres eneste specifikke kendetegn er immunitet i forhold til døden. Og ifølge Homer selv sang han om guderne, sådan som han nu engang gjorde, fordi en guddommelig muse sendte ham denne sang.

Vi bliver nødt til at spørge os selv, hvorfor vi ikke tager disse åbenbaringspåstande alvorligt. Min formodning er: fordi vi tror, at store filosoffer eller digtere må have brugt den slags billeder udelukkende som retoriske ornamenteringer. Men det er alene vores fordom; der er ikke belæg for det i teksterne. Sokrates sagde, han havde en damon. Han må - insisterer vi så på - have ment, at han havde en indre skuen af sandheden. Og det var rigtignok, hvad han selv mente, men han troede samtidig, at grunden hertil var, at han var grebet af en magt hinsides ham selv.

Hvis vi tager Athen på ordet, så ligger kontrasten mellem Athen og Jerusalem faktisk ikke i en forskel mellem fornuft og åbenbaring, men mellem to åbenbaringer, der hver især muliggør en rationel 
tænkning, og som på hver sin måde underlægger sig denne. Om nøjagtig den samme relation gør sig gældende mellem Jerusalem og fx skyggen fra det berømte baobabtræ, skal jeg ikke kunne sige, men jeg kan ikke se nogen a priori grund til, at det ikke skulle være tilfældet.

Derfor foreslår jeg: hvis de spørgsmål og modpåstande, evangeliet støder på, når det invaderer et nyt religiøst og moralsk territorium, ikke blot er falske og absurde, så er det fordi, de opstår ud af sand åbenbaring. Og hvis Israels Gud er den eneste Gud - hvis han ikke er, så er han ud fra sine egne kriterier en falsk gud - så må det være ham, der står bag sådanne åbenbaringer. Men ender vi så alligevel med at vende tilbage til billedet af ét bjerg med mange veje til toppen?

Her er en distinktion nødvendig. At Gud aldrig og intetsteds lader sig være uden vidnesbyrd, er én ting. Hvad vi siger eller gør som svar på eller i videreformidlingen af hans åbenbaring, er noget andet. Talte Gud til Muhammed? Ja. Sagde han det, Muhammed skrev ned? Ikke nødvendigvis. Ville de mennesker i Kana'an, der ofrede deres børn til Molok, have gjort det, hvis ikke Gud havde talt til dem? Nej - for hvis Gud ikke havde talt til dem, ville de slet ikke have ofret. Sagde Gud til dem, at hans navn var Molok, og at han elskede duften af brændte børn? Nej. Molok var en anden Gud end Herren, og Herren er frem for alt nidkær. Alligevel kan selv ikke tilbederne af Molok udelukkende være bærere af usandhed; i så fald ville det ikke engang være muligt at fordømme dem.

Derfor ligger, som Paulus siger, det "man kan vide om Gud ... åbent for" alle, for "Gud har jo åbenbaret det for dem." Men som Paulus også siger, udover i Kristus tilbeder vi, der er modtagere af åbenbaringen, rent faktisk skabninger; i stedet for Den Åbenbarende tilbeder vi åbenbaringens formidlere, der netop derfor bliver til levende, ødelæggende ånder. Hvilket vil sige, de bliver afguder. Al religion responderer på sandheden og må derfor indeholde sandhed. Og alle folkeslagenes guder er afguder.

\section{IV}

Hvordan kan det overhovedet lade sig gøre, at Gud taler til os, og at vi derpå gentager noget, han ikke sagde? Ville en henvendelse fra Gud ikke feje vores skammelige evne til at misforstå af vejen? Jo, selvfølgelig - hvis Gud henvendte sig direkte til os og talte sit modersmål. Men så ville han knuse os. Derfor taler Gud gennem andre formidlende stemmer - som Luther formulerede det, taler Gud gennem masker af sig selv. Det åbner muligheden for vores fejltagelser. 
Gud taler sin Torah til os gennem samtalen i de samfund, vi lever i. For vi kan kun leve sammen, når vi vedholdende siger til hinanden, "du skal gøre dette, og du må ikke gøre dette". "Du må ikke slå ihjel på eget initiativ", siger vi, og vi er tvunget til at sige sådan for overhovedet at være i stand til at leve sammen. Netop sådan lyder Guds Torah iblandt os.

Gud taler sit evangelium til os gennem profeterne (eller nogle, der minder om dem) i de samfund, vi lever i. For hvis Torahens ord i samfundet ikke er baseret på nogen højere autoritet end de personer, der offentligt ytrer dem, så vil dette samfund, så snart dets konstituerende moral konfronteres med en alvorlig udfordring, svæve rundt i et tomrum af usikkerhed om dets egen identitet. I så fald kræves der et ord fra oven - hvordan det så end vil lyde. Men før eller siden må dette "mandat fra himlen" lyde, auspicierne må afsløre en chokerende sandhed, eller hvad det nu kan være. Guds evangelieord: "Frygt ikke, for jeg er med jer", vil - eller vil ikke - blive talt for at redde samfundet.

Netop derfor er det muligt for os at sige til hinanden, "men er det virkelig, hvad Gud siger?", "er det ikke snarere, hvad samfundet vil have mig til?", "må en mere sandsynlig Torah ikke snarere lyde 'du skal ikke tage døden i dine egen hænder, med mindre det virkelig er nødvendigt'?" Og netop derfor bliver det også muligt for os at svare, "at bevare tilliden til Guds godhed er for svært for os. Skal vi ikke hellere bare stole på os selv?”

Det er rent faktisk på denne måde, vi svarer Gud, når han taler gennem vores gensidige samtale. At vi gør det, er uforklarligt. Det er syndens mysterium. Eller som Colin Gunton engang formulerede det, "vi kan ikke adlyde Gud, og vi kan ikke, fordi vi ikke vil."

Derfor bør kirken opfatte andre religioners tilhængere som nogle, der bliver tiltalt af den sande Gud, og som nogle, der henvender sig til den forkerte, når de forsøger at svare ham, og når de i deres fællesskaber udtaler sig om ham. Vi bør betragte dem som nogle, der står over for en collage, der både består af sand kundskab om den ene Gud og af afgudsdyrkelse. Og når vi fortæller dem om Opstandelsen, skal vi regne dem for at være nøjagtig den slags samtalepartnere.

Der er endnu to punkter, vi må se nærmere på. Vi må spørge: hvorfor rammer den samme kritik ikke vores egen religion? Hvorfor er vores forkyndelse og bønner ikke en forvrængning af Guds tale til os? Og vi må tage med i betragtning, at ikke kun kristendommen har sin 
egen relation til de andre religioner, men at hvert af disse andre bjerge selv er placeret forskelligt på kortet over bjergene. Jeg vil berøre disse spørgsmål i denne rækkefølge.

I udgangspunktet må vi sige med Karl Barth, at den religionskritik, jeg lige har hengivet mig til, så sandelig også skal bruges imod vores egen religion. Hvad der bliver sagt og gjort i kirkerne, vil på ethvert givet tidspunkt være en blanding af sandhed og løgn om, hvad Gud siger, og hvad vi fejlagtigt siger, at han siger. Men enhver religion rummer sine egne specifikke påstande, og en afgørende påstand $\mathrm{i}$ vores tro - hvis den er sand - forhindrer en sådan selvkritik i at være suicidal. Hvordan det så står til med andre religioner, må vi overlade til dem.

For hvis vores tro er sand, så er der et sted, hvor det Gud siger, og det vi siger, han siger, ganske enkelt er sammenfaldende: Inkarnationen, virkeliggørelsen af Guds Ord som et menneskes budskab, lidelse, og handlinger. Og det er virkelig, hvad Inkarnationen er: sammenfaldet mellem, hvad en af os siger for og om Gud, og hvad Gud siger for og om sig selv.

Og nu det andet af de to punkter. Under de nuværende omstændigheder må mit eksempel nødvendigvis blive: hvad med islam? Hvordan skal vi betragte den?

Jeg kan ikke hævde at besidde et kendskab til islam, som en muslim ville anerkende, eftersom jeg ikke kan læse arabisk. Alligevel - jeg var engang tilknyttet en kirkelig kommission, der var nedsat med henblik på at overveje, hvordan den kristne teologi ville se ud, hvis den blev formuleret i koran'ske begreber; hensigten var at forsøge at åbne for studier af den art, som nu engang kan lade sig gøre gennem andre sprog og med hjælp fra en eminent arabiskkyndig. Det blev mit lod at udfolde Treenigheden ved hjælp af begreberne om profeten, rasul, sådan som Moses og Jesus siges at være, og det absolutte forbud mod shirk, det at sætte noget som helst ved siden af Gud - et forbud der, når alt kommer til alt, er lige så vitalt for jødedommen og kristendommen, som det er for islam. Jeg kan måske tilføje, at jeg dengang nåede frem til et mere håbefuldt syn på islam, end jeg er tilbøjelig til at have i dag. Jeg har nemlig siden hen været en del af en øvelse i en fælles jødisk/muslimsk/kristen læsning af Skriften.

De kristne tænkere, der som de første blev nødt til at forholde sig til islams tilstedeværelse, opfattede den for det meste som et kristent kætteri. Nu kan et samfund, der helt igennem står uden for kirken, selvfølgelig ikke i egentlig forstand udgøre et kristent kætteri. Men Muhammed vidste helt givet noget om kristendommen og synes faktisk ind imellem at have forstået sin mission som det at skulle give sit folk en bog, der var lavet ud fra samme model som de bøger, som jø- 
derne og de kristne havde. Desuden hævder koranen jo faktisk at kende sandheden om Jesus som Kristus.

Hvori kan kætteriet så bestå? Jeg vil påstå: i udskiftningen af Ordet som person med Ordet som bog - kristen fundamentalisme af den amerikanske type gør ofte noget tilsvarende. Koranen er, i størstedelen af muslimsk teologi, uskabt, selve teksten eksisterer ned til mindste detalje i Guds egen evighed, og kan derfor ikke oversættes.

Og hvad bør så missionens særlige form være i forhold til det islamiske folk, der i dag er under opbygning i det område, vi engang kaldte Europa? Vi bør helt fra begyndelsen forvente en vis rigiditet $\mathrm{i}$ responsen, eller alternativt en vis ubestemthed, hvilket næppe kan være anderledes, når det drejer sig om en religion, der har en bog som sin åbenbaring og sit nådemiddel. Fordi selve teksten er Guds egen tekst, har det meste af islam - undtagen naturligvis der hvor den kun findes af navn - meget lidt at diskutere med kristendommen eller med nogen som helst andre, eftersom en samtale foregår mellem personer, og det er deres Logos ikke. Men der er jo også sufierne, som, netop fordi bogen er Guds sande bog, mener, at den siger alt og hvad som helst, og som derfor higer efter billedlige læsninger, der făr Origenes til at ligne en bogstavtro fundamentalist.

Der hvor kirken kan få øje på nogen som helst form for åbning, skal dens overordnede projekt i den islamiske sammenhæng måske være humanitet: en samtale - hvis vi kan få nogen til at deltage - om Guds menneskelighed og de former for bønner og liv, der er mulige, når der er en Uskabt, som er én af os. Ligesom Paulus i Athen begyndte med verdens realitet og forskellen mellem at tilskrive dens realitet til en person og at opfatte den som sin egen selvberoende årsag, således kunne man måske begynde i Europa med forholdet og forskellen mellem tro på en guddommelig bog og tro på en menneskelig guddommelighed.

Oversat af cand.theol. Karsten Farup Hansen og ph.d. Lars Sandbeck. 